\title{
Diversity and endemism in the pyrenocarpous lichen families Pyrenulaceae and Trypetheliaceae in the Malesian flora region
}

\author{
A. Aptroot ${ }^{1}$
}

Key words

endemism

lichens

Pyrenulaceae

Trypetheliaceae

\begin{abstract}
Species diversity and local endemism is investigated in the pyrenocarpous lichen families Pyrenulaceae and Trypetheliaceae in the Malesian flora region and some peripheral regions. Species numbers in both families seem highest in Australia and Papua New Guinea, but some potentially rich regions are much undercollected. The numbers of local endemics are also highest in these areas, at least in the Pyrenulaceae, and remarkably high for lichens. Even more surprising is the near absence of species confined to two adjacent regions.
\end{abstract}

Published on 30 October 2009

\section{INTRODUCTION}

Pyrenocarpous lichens are a conspicuous element in the epiphyte flora of the tropics: if you ever thought that the bark of rain forest trees is often green, you are mistaken: what you see are actually pyrenocarpous lichens. They are quite speciose, and many, for instance the Porinaceae, seem to be restricted to areas with a long ecological continuity, and prefer primary rain forest rather than secondary rain forest (Rivas Plata et al. 2008).

Three families, viz. the Porinaceae, Pyrenulaceae and Trypetheliaceae, comprise the vast majority of the species, each with several hundred species. In the past decades they have been the subject of rather intense taxonomic studies in much of the Malesian flora region, especially the periphery, and recently also in Australia. This facilitates the comparison between the pyrenocarpous lichen flora of various countries, and a preliminary assessment of the degrees of endemism in these groups

This paper focuses on the Pyrenulaceae and the Trypetheliaceae, as a biogeographical account of the family Porinaceae was recently published (McCarthy 2003).

\section{HISTORY}

The two families, Pyrenulaceae and Trypetheliaceae, are generally studied jointly as their delimitation has been disputed and has actually been changed several times. The main differences are the colour of the mature ascospores (usually hyaline in the Trypetheliaceae, grey to brown in the Pyrenulaceae) and the branching of the hamathecium filaments (anastomosing in the Trypetheliaceae, mostly unbranched in the Pyrenulaceae); both are microscopical characters that sometimes have been misjudged due to inadequate material or observations. Despite their similarities they are phylogenetically well separated: molecular analysis (Del Prado et al. 2006) confirms the Trypetheliaceae as monophyletic and places the family in Dothideomycetes. The Pyrenulaceae, which were previously classified with the Trypetheliaceae in the Pyrenulales or Melanommatales, are supported in the same molecular analysis as monophyletic and belonging to the Chaetothyriomycetes.

\footnotetext{
ABL Herbarium, Gerrit van der Veenstraat 107, 3762 XK Soest, The Netherlands.
}

Until two decades ago, almost all information about pyrenocarpous lichens in the Malesian area dated from the 19th century. Since then, pyrenocarpous lichens have been studied in the field in many countries, and usually the existing herbarium specimens from these areas have been revised.

\section{SOURCE OF DATA}

The data for this study were compiled from various sources, as current knowledge of the pyrenocarpous lichens in the Malesian area and some peripheral countries differs from one region to the other, as follows:

Australia - Based on a limited set of specimens from the 19th century, c. 100 species were known in these two families, over half of which were described and still only known from Australia. A huge amount of recent material has been identified, where necessary, and is included in this study. All these were examined by the author in the framework of the Flora of Australia (Aptroot 2009a, b), as an addition to McCarthy (2001), who treated the Porinaceae. In some preliminary publications (Aptroot 1997, 2007), most new taxa and combinations were published, as well as the records from Australia's oceanic islands (Aptroot 2008).

New Guinea - All data are based on personal observations (Aptroot et al. 1997, Aptroot 1998). This information is largely confined to Papua New Guinea; virtually nothing is known from Irian Jaya or Papua Barat, as no attention was paid to lichens during historic and recent expeditions alike.

Indonesia - Although this constitutes the largest country of the Malesian region, very little is known about the pyrenocarpous lichens, or even lichens in general. The main source, and that only for Java, is Zahlbruckner (1943), who proved to be rather unreliable in the case of the pyrenocarpous lichens from Taiwan (Aptroot 2004). Therefore, no estimates can be given for the number of species and endemics for any of the Indonesian islands. Little attention was paid to lichens during historic and recent expeditions alike. Most specimens available for study were collected by non-specialists and represent the same weedy species over and over again. As long as no lichen specialists are included in collecting expeditions in Indonesia, this will remain a black hole.

(c) 2009 Nationaal Herbarium Nederland

You are free to share - to copy, distribute and transmit the work, under the following conditions:

Attribution: You must attribute the work in the manner specified by the author or licensor (but not in any way that suggests that they endorse you or your use of the work). 
Sabah and Brunei - Lichen expeditions have visited Mt Kinabalu (Sipman 1993) and the Mulu region. The first is at too high an elevation for a diverse pyrenocarpous lichen flora; the pyrenocarpous lichens from the second have only received fragmentary attention, e.g. by McCarthy \& Elix (1996).

Malaysia and Singapore - The only part that received any attention, and for which the pyrenocarpous lichens are well known, is Singapore (Sipman 2007 and this volume). The numbers of pyrenocarpous lichens are not given here as the area is comparatively small.

Philippines - Collecting of lichens by general botanists started in the beginning of the 20th century. This material received quite some attention by a lichenologist (Vainio 1920), who unfortunately had insufficient knowledge of the tropical species already described at that time from other areas. Therefore virtually every specimen was described as a new species. As the characters now used to distinguish the species (e.g. UVfluorescence and ascospore lumen shape) were not noted, and many specimens have not been restudied since, it is difficult to estimate how many of the species described from the Philippines are indeed endemics. The only notable recent publication citing pyrenocarpous lichens from the Philippines is Aptroot \& Sipman (1990), which was based on only one week field work and does not report endemic species.

Vietnam - Aptroot \& Sparrius (2006) cite all lichens, pyrenocarpous or not, ever reported from Vietnam, to which they add a substantial number, based on only one week of field work. The country is quite extended and the number of species is

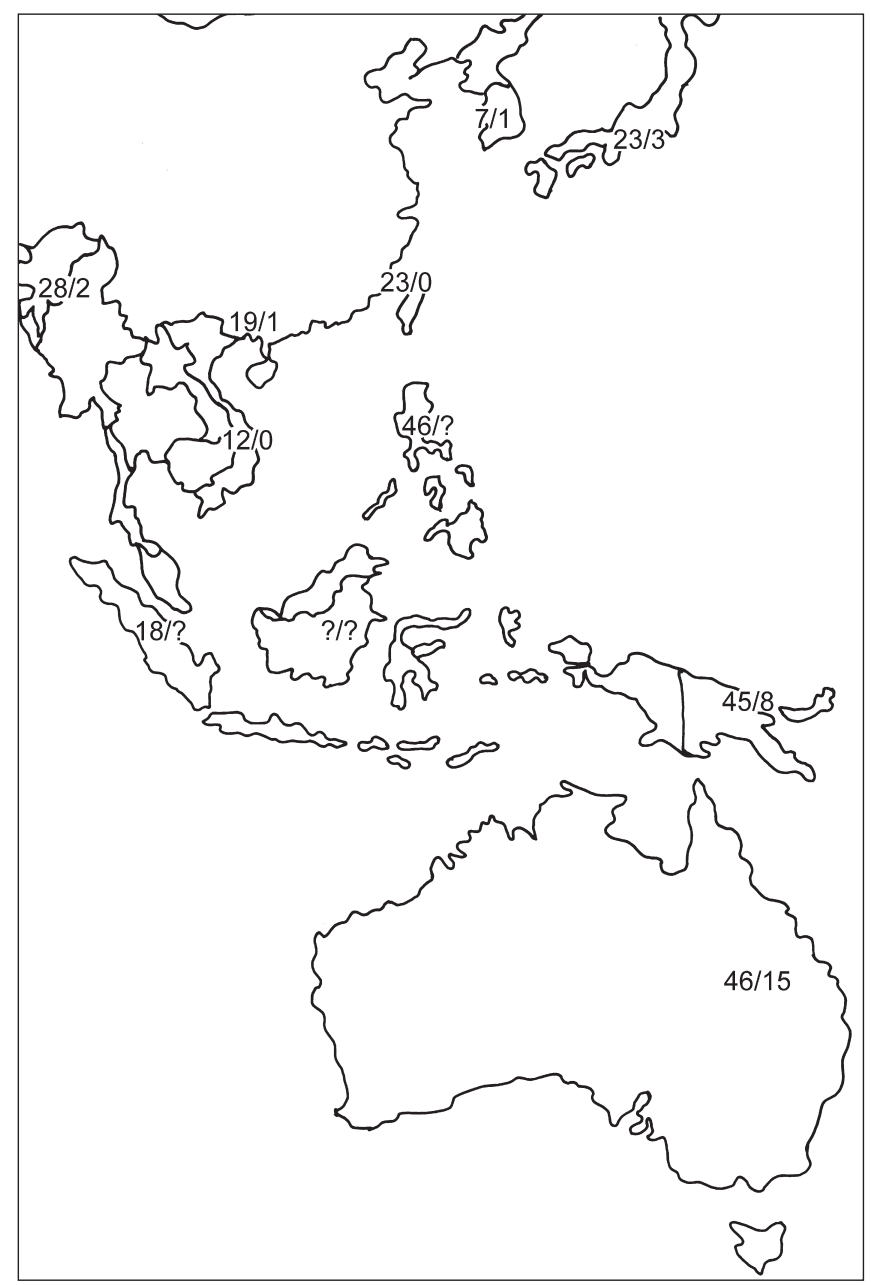

Map 1 Number of Pyrenulaceae species (before slash) and number of endemic Pyrenulaceae (after slash) for some countries in the Malesian flora region. expected to rise when the more distant and generally less disturbed border regions are investigated.

Thailand - Wolseley et al. (2002) give a checklist, in which the only paper with a substantial amount of pyrenocarpous lichens, that by Vongshewarat et al. (1999) is already included. Aptroot (2006) and Aptroot et al. (2007) provide many additions, roughly doubling the number of pyrenocarpous lichens and describing new endemic species based on fieldwork by the authors.

Laos, Cambodia and Myanmar — Virtually nothing is known about lichens, pyrenocarpous or otherwise, in these countries.

Yunnan - Southern Yunnan is tropical and has a rich and diverse pyrenocarpous lichen flora, which has only recently received attention (Aptroot et al. 2003, Aptroot 2002, 2006).

For a comparison with the more tropical regions, the numbers of species are given here from a few more peripheral countries:

Hong Kong - Although not strictly tropical, this area has recently received ample attention from lichenologists (Aptroot \& Seaward 1999, Aptroot \& Sipman 2001). The numbers of pyrenocarpous lichens are not given here as the area is comparatively small.

Taiwan - The pyrenocarpous lichens of Taiwan were recently investigated, based on field work (Aptroot 2003) and on a re-investigation of the, comparatively small amount of existing herbarium specimens (Aptroot 2004).

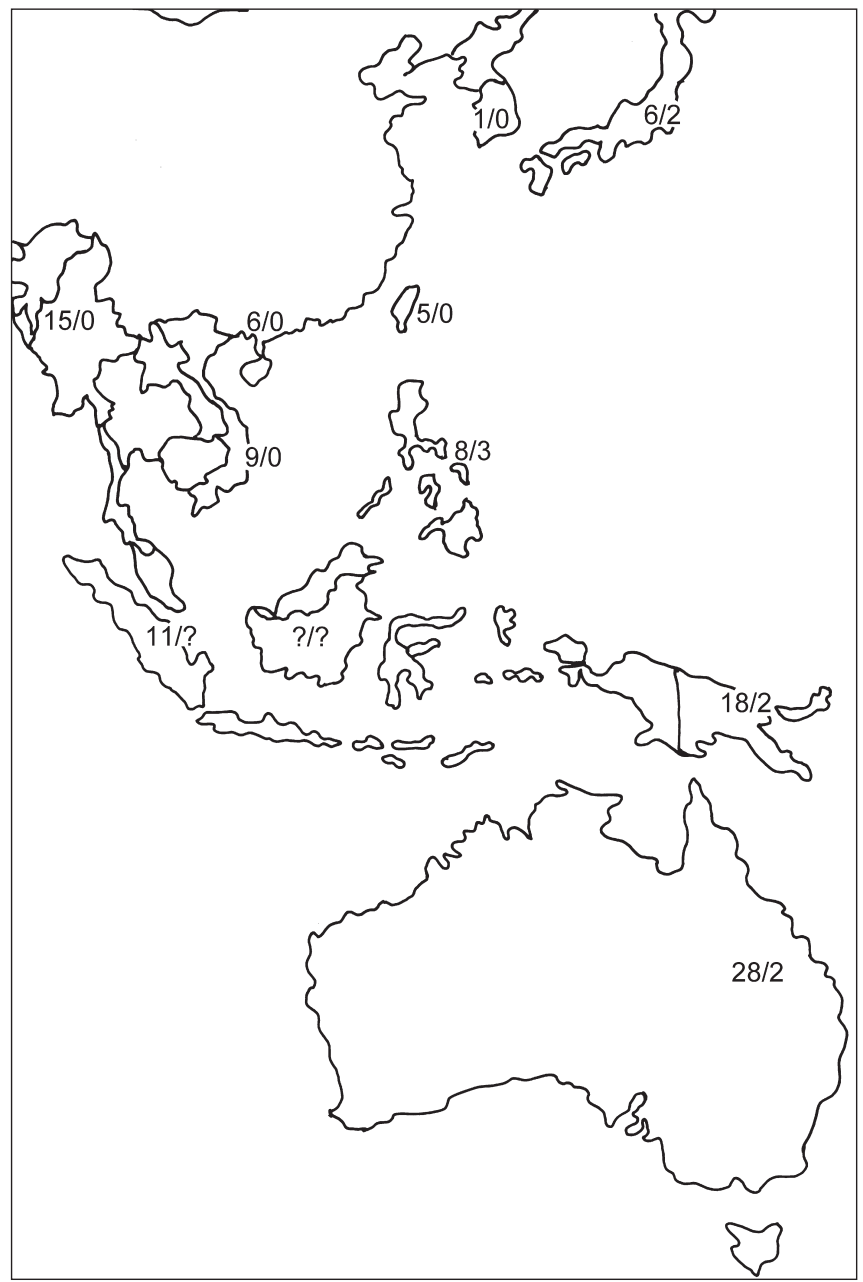

Map 2 Number of Trypetheliaceae species (before slash) and number of endemic Trypetheliaceae (after slash) for some countries in the Malesian flora region. 
Korea - The pyrenocarpous lichens from Korea were also recently investigated, based on field work and on a revision of the, comparatively sparse, existing herbarium material (Moon \& Aptroot 2009).

Japan - Finally, the pyrenocarpous lichens from Japan (which ranges from fully tropical to nearly boreal) were investigated based on a revision of most material in the TNS herbarium (Kashiwadani et al. 2009). For this study, those literature records are added that are certain to represent additions.

\section{RESULTS AND DISCUSSION}

The total numbers of species in the families Pyrenulaceae and Trypetheliaceae reliably known from a certain region, and the numbers of supposedly endemic species, are presented in Map 1 and 2 for several countries in the Malesian flora region.

Species numbers in both families seem highest in Australia and Papua New Guinea, but some potentially rich regions are much undercollected. The numbers of local endemics are also highest in these areas, at least in the Pyrenulaceae, and remarkably high for lichens.

The Pyrenulaceae from Papua New Guinea include several endemic Pyrenula species (Aptroot et al. 1997) that occur especially at high elevation (where generally few pyrenocarpous lichens occur). The Pyrenulaceae of Australia stand out because they contain three small groups of closely related endemics: The species pair consisting of Anthracothecium gregale (C.Knight) Aptroot and A. toowoombense (Müll. Arg.) Aptroot (Aptroot 2007); the species pair consisting of Pyrenula subumbilicata (C.Knight) Aptroot and P. subvariolosa (C. Knight) Aptroot (Aptroot 2007); and the species pair consisting of Lithothelium hieroglyphicum Aptroot and L. nanosporum (C.Knight) Aptroot, of which only the latter one is known also from outside Australia (Aptroot 2007). However, most of the nearly 100 supposed endemics earlier described from Australia turned out to be synonyms of pantropical species (Aptroot 2007). The genus Pyrgillus is especially well-represented in Australia, with all known species present.

The Trypetheliaceae from Papua New Guinea include several endemics, e.g. a Pseudopyrenula and a Trypethelium described by Aptroot (1998), again especially occurring at high elevation. Remarkably, one of these (Trypethelium galligenum Aptroot (1998: 29) is harming its host tree, which responds by gall-formation by the bark. This is very unusual for lichens, which normally do not harm or even interact with their host trees. In Australia, more Trypetheliaceae occur, most of which are pantropical (Aptroot $2009 b)$. The genus Polymeridium, is especially well-represented, with e.g. a rather common species endemic to Australia.

It is surprising that species strictly confined to two adjacent regions are rare. For instance, apart from a large set of pantropical taxa that the adjacent areas Papua New Guinea and Australia regions share, they generally have few species of Pyrenulaceae and Trypetheliaceae in common, only one of which, viz. Pyrenula laureriformis Aptroot (Aptroot et al. 1997, Aptroot 2007, 2009a) seems confined to both regions. The same can be observed for other pairs of adjacent areas: although there is a certain resemblance between the pyrenocarpous lichen flora of e.g. Thailand and Yunnan, only few species are restricted to these two regions.

Acknowledgement This work was carried out with the support of a grant from the Australian Biological Resources Study.

\section{REFERENCES}

Aptroot A. 1997. Additional lichen records from Australia 30. New records of Pyrenocarps. Australian Lichenological Newsletter 40: 4-7.

Aptroot A. 1998. New lichens and lichen records from Papua New Guinea, with the description of Crustospathula, a new genus in the Bacidiaceae. Tropical Bryology 14: 25-34.

Aptroot A. 2002. Lichens of Yunnan, collected Oct. 2002 by A. Aptroot. Published on the internet: http://www.toyen.uio.no/botanisk/lav/Yunnan/ Yunnanlistdutch I.doc.

Aptroot A. 2003. Pyrenocarpous lichens and related non-lichenized ascomycetes from Taiwan. Journal of the Hattori Botanical Laboratory 93: 155173.

Aptroot A. 2004. Redisposition of some, mostly pyrenocarpous, lichen species described by Zahlbruckner from Taiwan. Symbolae Botanicae Upsalienses 34: 31-38.

Aptroot A. 2006. Three new species of Lithothelium from China and Thailand, with a revised world key. Lichenologist 38: 541-548.

Aptroot A. 2007. New species, combinations, lectotypifications and synonyms in Australian Pyrenulaceae. Australasian Lichenology 60: 34-41.

Aptroot A. 2008. Additional lichen records from Australia 65. Pyrenulaceae from Lord Howe, Norfolk and Cocos (Keeling) Islands. Australasian Lichenology 62: 6-8.

Aptroot A. 2009a. Pyrenulaceae. Flora of Australia 57: 449-480.

Aptroot A. 2009b. Trypetheliaceae. Flora of Australia 57: 534-552.

Aptroot A, Diederich P, Sérusiaux E, Sipman HJM. 1997. Lichens and lichenicolous fungi from New Guinea. Bibliotheca Lichenologica 64: 1-220.

Aptroot A, Ferraro LI, Lai M-J, Sipman HJM, Sparrius LB. 2003. Foliicolous lichens and their lichenicolous ascomycetes from Yunnan and Taiwan. Mycotaxon 88: 41-47.

Aptroot A, Saipunkaew W, Sipman HJM, Sparrius LB, Wolseley PA. 2007. New lichens from Thailand, mainly microlichens from Chiang Mai. Fungal Diversity 24: 75-134.

Aptroot A, Seaward MRD. 1999. Annotated checklist of Hong Kong lichens. Tropical Bryology 17: 57-101.

Aptroot A, Sipman HJM. 1990. New lichen records from the Philippines. Acta bryolichenologica asiatica 1: 31-41.

Aptroot A, Sipman HJM. 2001. New Hong Kong lichens, ascomycetes and lichenicolous fungi. Journal of the Hattori Botanical Laboratory 91: 317-343.

Aptroot A, Sparrius LB. 2006. Additions to the lichen flora of Vietnam, with an annotated checklist and bibliography. The Bryologist 109: 358-371.

Del Prado R, Schmitt I, Kautz S, Palice Z, Lücking R, Lumbsch HT. 2006. Molecular data place Trypetheliaceae in Dothideomycetes. Mycological Research 110: 511-520.

Kashiwadani H, Aptroot A, Moon, KH. 2009. Pyrenocarpous lichens of Japan, with the resurrection of the genus Trypetheliopsis. Bibliotheca Lichenologica 99: 247-258.

McCarthy PM. 2003. Catalogue of the lichen family Porinaceae. Bibliotheca Lichenologica 87: 1-164.

McCarthy PM, Elix JA. 1996. Myeloconis, a new genus of pyrenocarpous lichens from the tropics. Lichenologist 28: 401-414.

McCarthy PM (ed). 2001. Flora of Australia. Volume 58A, Lichens 3. ABRS/ CSIRO Australia, Melbourne.

Moon KH, Aptroot A. 2009. Pyrenocarpous lichens in Korea. Bibliotheca Lichenologica 99: 297-314.

Rivas Plata E, Lücking R, Lumbsch HT. 2008. When family matters: an analysis of Thelotremataceae (lichenized Ascomycota: Ostropales) as bioindicators of ecological continuity in tropical forests. Biodiversity and Conservation 17: 1319-1351.

Sipman HJM. 1993. Lichens from Mount Kinabalu. Tropical Bryology 8: 281314.

Sipman HJM. 2007. List of the lichen genera of Singapore. http://www.bgbm. org/BGBM/STAFF/Wiss/Sipman/Zschackia/Singa/genuslist.htm.

Vainio EA. 1920. Lichenes Insularum Philippinarum III. Acta Societatis Scientiarum Fennicae 15: 1-368.

Vongshewarat K, McCarthy PM, Mongkolsuk P, Boonpragob K. 1999. Additions to the lichen flora of Thailand. Mycotaxon 70: 227-236.

Wolseley PA, Aguirre-Hudson B, McCarthy PM. 2002. Catalogue of the lichens of Thailand. Bulletin of the Natural History Museum, London, Botany 32: 13-59.

Zahlbruckner A. 1943. Flechtenflora von Java. 1. Feddes Repertorium Specierum Novarum Regni Vegetabilis. Beiheft 127: 1-80. 